\title{
The Changing Workforce And Marketplace
}

Terry L. Howard, (E-mail: thoward@ mibln.org), Business Leadership Network of Michigan

Gregory W. Ulferts, (E-mail: ulfertgw@udmercy.edu), University of Detroit Mercy

\begin{abstract}
The makeup of the labor force has changed dramatically in the last 25 years and will continue to change at an even faster pace. Businesses and/or organizations will achieve many benefits from including the ageing population and people with disabilities in both the workforce and marketplace. Viewing the ageing population and people with disabilities as strategic business partners will achieve a strong, competitive advantage.
\end{abstract}

\section{THE LABOR MARKET}

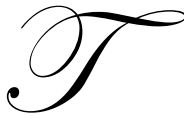

he makeup of the labor force has changed dramatically in the last 25 years and will continue to change at an even faster pace with today's technology leading the way. Some would say that the primary source of sustainable, competitive advantage is not superior products, technology, or any other physical assets; but is the recruitment and retention of talented employees. To retain the top talent in a tight labor market, companies are adopting newer techniques in order to be successful.

Businesses are beginning to realize that it makes no sense to exclude roughly 20 percent of the nation's population - people with disabilities. This number will continue to grow with the aging population - baby boomers coming of age. Employers' attitudes toward people with disabilities and the ageing population still retain outdated perceptions about what is required to make a workplace successful.

Ensuring we have the best people with the skills required for the changing environment; capitalizing on the range of available employee capabilities; developing a flexible workforce that is responsive to client needs; and adapting work practices to help respond to changing demands, both internal and external; are essential elements in the long-term success of any organization. Planning for a high performing workforce will have a significant impact on the efficient and effective delivery of quality service.

The ageing and people with disabilities populations are set to change the shape of our workforce over the coming years. New technologies in the next 10 to 20 years offer tremendous potential to revolutionize the way education and training is delivered to improve efficiency and effectiveness in learning. Such learning programs will become increasingly sophisticated over time with advances in hardware and software, including artificial intelligence, voice recognition and natural language comprehension. These populations will also benefit from improvements in intelligent tutoring systems that allow self-paced, interactive, self-improving learning.

\section{THE AGEING POPULATION}

The number of young people entering the workforce over the next few decades will be considerably fewer than the number of people retiring. The result will be a decline in the workforce in many countries, which will probably start happening around 2014. As fewer young people join the workforce, recruiting will become more difficult. Employers will have to create more flexible working arrangements to retain older employees.

Americans over 50 make up 35\% of the nation's population, and have $77 \%$ of the financial assets and $57 \%$ of the discretionary income. ${ }^{12}$ This coupled with the proportion of the workforce over 45 in the next decade will force employers to reexamine how they are going retain and accommodate the ageing population so not to lose that level of experience in the workforce. With skill demand changes in the workforce, employers will have to make accommodations for the ageing population to stay compatible in their area of business. 


\section{PEOPLE WITH DISABILITIES}

One in five people are living with a long-term impairment and/or disability. Employers that are making there workplaces accessible will benefit through increased retention of staff and customers. A qualified employee or applicant with a disability is an individual who, with or without reasonable accommodation, can perform the essential functions of the job in question. Technology can level the playing field for the disabled and remove the workplace barriers they face.

An individual with a disability is a person that has a physical or mental impairment that substantially limits one or more major life activities/functions. Disabilities can be recognized in two ways. First, one that has a record of such impairment. Second, one that is regarded as having such impairment.

With approximately 56 million people with disabilities in the U.S., almost one in five people are potential customers for businesses that are disability-friendly. ${ }^{8,9}$ People with disabilities are a large and growing market, with $\$ 175$ billion in discretionary spending. Customers with disabilities will patronize businesses that are welcoming, helpful, accessible, and provide quality products and services at competitive market prices. ${ }^{10}$

Survey data shows that $92 \%$ of consumers feel favorable toward companies that employ people with disabilities and $87 \%$ would prefer to give their business to such companies. ${ }^{11}$

These data provide compelling reasons for businesses to develop strategic initiatives.

As people age, they are likely to experience changes that may affect hearing, vision, cognition and mobility. While older adults may not think of themselves as having disabilities, they often seek out businesses that accommodate the changes they have experienced. ${ }^{9}$ Businesses can enhance their competitive edge by ensuring that people with disabilities are integrated into the workforce and customer base. ${ }^{14}$

\section{ACCOMMODATIONS}

Businesses have a misconception about the costs of accommodations. Accommodating people with disabilities has proven to cost less with high benefits in today's workforce. At least $66 \%$ of accommodations cost less than $\$ 500$, and $73 \%$ of employers report their employees with disabilities did not require accommodations. ${ }^{3}$ For every $\$ 1$ spent to make an accommodation, companies receive $\$ 35-\$ 45$ in benefits. ${ }^{4}$

Many disabilities are acquired later in life through a medical condition or accident. Therefore, many people with disabilities have a wealth of experience and maturity. ${ }^{2}$

Many employers have made accommodations to retain valued and qualified employees. ${ }^{1}$

Accommodating employees, with and without disabilities, leads to a loyal, dedicated and productive workforce.

Examples of low-cost accommodations include: flexible work schedules; adaptive software; ergonomic chairs, wrist supports, and foot rests; telecommuting; and many others. ${ }^{2}$ Quite often, companies have found that the accommodations needed by employees are totally different than what may have been anticipated. An open environment of communication can benefit everyone.

There are numerous organizations that are able to advise businesses. In some cases, these organizations will even provide accommodations. This requires that agencies and vendors (that exist to serve the employment needs of people with disabilities) recognize and respond to the fact that employer satisfaction is a fundamental service outcome that must be addressed to guarantee their success and survival. 


\section{BENEFITS FOR EMPLOYERS}

Long-term studies have shown that employees with disabilities meet or exceed supervisors' requirements and stay with employers 50 percent longer than other employees. Attendance records for people with disabilities and the ageing population are as good as, or better than, those of non-disabled workers. Many people with disabilities and the ageing population are educated, experienced and qualified to meet an employer's workforce needs.

People with disabilities have $\$ 175$ billion in discretionary income and patronize businesses that are "disability-friendly" - hiring, welcoming, and accessible to people with disabilities. ${ }^{9,10}$ Consumers feel positively toward, and prefer to do business with companies that employ the ageing population and people with disabilities. 7 There are tax benefits for hiring and accommodating qualified people with disabilities. ${ }^{6}$

People with disabilities, once hired and properly accommodated in their jobs, are not "workers with disabilities", but simply workers. People with disabilities and the ageing population can enhance an organization's diversity initiatives. ${ }^{2}$ This is the ultimate goal.

\section{CONCLUSION}

In the future, businesses and/or organizations will achieve many benefits from including the ageing population and people with disabilities in both the workforce (actively recruit, hire, train, advance, and support workers with disabilities because doing so raises productivity) and marketplace (actively market products and services to consumers with disabilities because doing so creates profit. Viewing the ageing population and people with disabilities as strategic business partners will achieve a strong, competitive advantage.

\section{REFERENCES}

1 Job Accommodation Network. Workplace Accommodations: Low Cost, High Impact.

2 Employer Assistance \& Recruiting Network. www.earnworks.com.

3 Virginia Commonwealth University, Rehabilitation Research \& Training Center on Workplace Supports and Job Retention. The Realities of Hiring People with Disabilities. June 2005.

$4 \quad$ Job Accommodation Network, www.jan.wvu.edu.

5 U.S. Department of Labor, http://www.dol.gov/odep/pubs/ek98/provide.htm.

$6 \quad$ U.S. Department of Labor, http://www.dol.gov/odep/pubs/ek97/tax.htm.

7 University of Massachusetts Boston, Center for Social Development and Education Press Release January 2006. http://www.usbln.com/Press_Release_Employment_Study.pdf.

82004 American Community Survey: www.factfinder.census.gov.

9 U.S. Department of Justice. Expanding your Market...Customers with Disabilities. http://www.ada.gov/busstat.htm

10 U.S. Department of Labor, http://www.dol.gov/odep/pubs/ek98/provide.htm.

11. University of Massachusetts Boston, Center for Social Development and Education Press Release January, 2006 http://www.usbln.com/Press_Release_Employment_Study.pdf.

12. William D. Novelli, AARP. How Aging Boomers Will Impact American Business http://www.aarp.org/about aarp/aarp_leadership/on_issues/baby_boomers/how aging boomers will impa ct american business.html.

13 National Organization on Disability. The Top 10 Reasons to Hire People with Disabilities. June 28, 2001. www.nod.org.

14 Solutions Marketing G. 


\section{NOTES}

